\title{
La Reinvención de la Vejez - Guita Grin Debert
}

Traducción y Reseña: Marta Inés Arabia ${ }^{1}$

\section{La autora:}

Guita Grin Debert es profesora titular de Antropología de la UNICAMP (Universidad de Campinas), es licenciada en Ciencias Sociales (1973), Máster en Ciencias Políticas (1977), Doctora en Ciencias Políticas por la Universidad de San Pablo y estudios de Pós-doctorado en el Departament of Anthropology, University of California, Berkeley (1989-1990). Fue Vicepresidente de la Asociación Brasilera de Antropología (2000-2002), miembro del comité académico de Ciencias Sociales (Antropología) del CNPq (2001 a 2003), editora de la Revista Brasilera de Ciencias Sociales, secretaria adjunta de la ANPOCS - Asociación Nacional de Pos-Graduación e Investigaciones en Ciencias Sociales (19921996) y coordinadora del PAGU (Núcleo de estudios de Género de la UNICAMP, 20072009. Es conferencista en diferentes universidades del mundo, entre ellas: Columbia University (EUA), Ecole Pratique des Hautes Etudes (Francia), Universidad de Bologna (Italia). Actualmente es miembro de la Coordinación de Ciencias Humanas y Sociales de FAPESP - Fundación de Amparo a la investigación del Estado de San Pablo. Tiene experiencia en el área de Antropología Urbana, actuando en partículas en las áreas: Vejez, familia, curso de la vida, género y violencia. Es autora de varios libros y artículos con estos temas.

DEBERT, Guita Grin. La reinvención de la vejez. Traducción Marta Inés Arabia. $1^{\mathrm{a}}$ ed. Buenos Aires: Siglo XXI Editora Iberoamericana, 2011, 248p.

Para quien dude de que el progreso científico y el desarrollo de conocimientos no se produce debido a una acumulación de datos generados a partir de los trabajos que se publican y, en cambio, provienen de hallazgos que ocurren con muy baja frecuencia, $\mathrm{La}$ reinvención de la vejez lo ayudará a convencerse de esto ofreciendo un original y lúcido análisis del proceso que orienta la construcción social de la vejez. Después de doce años de

\footnotetext{
${ }^{1}$ Marta Inés Arabia atualmente cursa Pós Doutorado em Literatura na UFSC concentrando-se na temática de velhice. Doutora em Letras pela UFSC em 2007 (área de concentração: Psicanálise e Literatura); Mestre em Linguística pela UFSC em 2000 (área de concentração: Psicanálise e Linguística); Especialista em Psicanálise pela Faculdades Integradas de Tuiti (área de concentração: Psicanálise Clínica); Graduada em Psicologia por resolução da Universidade Federal de Rio de Janeiro em 1993 e Graduada em Psicologia pela Universidad Argentina John F. Kennedy em 1987.
} 
publicada, ahora se traduce por primera vez al español conservando su poder de denuncia social.

Se trata de una obra sui generis en varios sentidos, pues fue publicada por primera vez en Brasil en el año 1999, lo que la vuelve pionera en términos literarios y científicos en tanto producción acerca del tema de la vejez

El contenido formal del libro se define a partir de dos momentos que se entretejen: el de la investigación propiamente dicha y el de su análisis. El trabajo de investigación es producto del recorrido realizado por una investigadora madura que conoce en profundidad su oficio. Su exhaustivo análisis trasciende los límites del saber legitimado que, como lo ha demostrado Debert, se ha dejado influir por los medios y por intereses creados en torno de un envejecimiento positivo, que favorece en especial a los nuevos mercados de consumo e, inclusive, a las políticas de Estado que, convenientemente, responsabilizan al añoso por sus pérdidas y limitaciones.

Manifestando una continuidad con el gesto que inaugura Simone de Beauvoir, Guita Grin Debert, suma fuerzas a lo que parece una tarea interminable: "quebrar la conspiración de silencio" construida en torno al tema de la vejez.

En este libro, la autora se enfoca en una descripción del añoso como nuevo protagonista social y, progresivamente, deja al descubierto aquello que se esconde detrás de bambalinas y de la pretendida neutralidad de los medios y de la ciencia.

$\mathrm{Si}$, por un lado los medios pueden representar la condición de la vejez en un primer plano que convierte al añoso en un actor privilegiado, por el otro, la reprivatiza devolviéndola a la esfera del silencio familiar y social, una vez que fue utilizada como un instrumento de negación de los problemas propios de aquella parte de la población que posee una edad avanzada.

Es en este sentido, las representaciones gratificantes de la tercera edad pasan a ser fuerzas activas de la "reprivatización de la vejez", pues, la visibilidad conquistada por las experiencias innovadoras y exitosas ocultan cuestiones difíciles de ser enfrentadas por el ser humano.

Debert, en el curso de su investigación, confronta al lector con la paradoja según la cual envejecer o morir fueran circunstancias provocadas por quien no ha sabido adherir a la propuesta de considerar a la "tercera edad" como la "mejor edad".

En la medida en que va construyendo una estructura cabal para sus argumentos, la autora incorpora citas de importantes referentes, fundamentando coincidencias o falta de coincidencias con ellos, con el fin de permitir una ampliación y un enriquecimiento del 
punto de vista de los lectores. El trabajo parte de una investigación orientada a verificar cuál es la imagen que los añosos tienen de sí mismos. La investigación se desenvuelve en asilos, programas para la tercera edad y asociaciones de jubilados para, finalmente, desentrañar de esa vertiginosa tela de araña una lectura integrada y racional. Una vez recogidos los valiosos relatos, Debert los confronta con las imágenes que ofrecen los medios y con aquellas que divulga una gerontología que se muestra "poco advertida", pues, en su afán de homogeneizar su corpus de conocimientos, puede perder toda su potencia crítica una vez que se vuelve ajena a la organización de su mundo de significados y a la manera en que estos adquieren sentidos. Los resultados son inusitados. En materia de vejez, la sociabilización puede ser también segregación y visibilidad, un “espectáculo” cuyo fin es la negación. Encontraremos, a lo largo del libro, una descripción de la reconfiguración de lo público y lo privado entre generaciones. La riqueza de la investigación cuenta con una descripción del proceso que se desarrolla respecto de la evolución de los derechos de los añosos en la sociedad brasilera, acompañado de las denuncias sobre el proceso de reprivatización de la vejez. Si por un lado existe una optimización de la calidad de vida, tal optimización, nos demuestra la lectura de La reinvención de la vejer, una vez llegado el momento de fragilidad y dependencia nos lanza directamente a un silencioso vacío. Guita Debert nos advierte: "vale la pena mirar con atención hacia las formas específicas en que se produce la reconfiguración de la vida moderna".

En particular y para concluir, como profesional dedicada al trabajo con la tercera edad y con las letras diré que algo me ha llamado poderosamente la atención: ¿por qué el psicoanálisis que ha periodizado su clínica desde sus inicios, inclusive implementando en los últimos años "la clínica del bebe", aún no le ha dedicado una clínica a la tercera edad? Luego, a pesar de que el libro constituye un gran suceso en Brasil, que se agota y reedita constantemente, todo indica que la mirada de los especialistas acerca de la vejez continúa ligada a lo que la autora denomina "envejecimiento positivo". Luego, todo sucede como si las denuncias expuestas por la antropóloga brasilera ocurriesen en un espacio de reflejos imposibles, donde apenas unos pocos pudieran entender el tenor y la gravedad que se esconde detrás de lo que se denuncia. Entiendo que este libro abre un archivo adormecido, Jacques Derrida lo llamaría “Archivo del mal”, estos archivos portan el silencio destructivo de aquellos sucesos cuya violencia desatan efectos que todavía poseen vigencia.

Años después de haber sido lanzado por primera vez en portugués, gran cantidad de la información de La reinvención de la vejez, restringida en aquel entonces a especialistas, en 
la actualidad constituye aspectos urgentes que involucran al conjunto de la sociedad. Incluso, diré, que se han radicalizado los miedos y el maquillaje que embellece a la "tercera edad" y la parafernalia tecnológica que lo impulsa.

El mundo humano está poblado del imperativo "tú debes", este imperativo tiene un efecto social al que la vejez en la modernidad no ha escapado. Junto con Zygmunt Bauman, diremos que la historia moderna constituye una prolífica fábrica de esos "deberes", en referencia a los modelos de "buena sociedad" que se alcanzarían a partir de estos.

La reinvención de la vejez evidencia la fuerza del imperativo "tú debes", respecto del que no es un exageración afirmar que se trata de un imperativo genocida cuando resulta inadvertido o silenciado.

El libro de Debert me ha invitado a pensar qué lugar tiene la fragilidad del ser humano en la vejez... ¿Será que el mismo sistema que los aplaude y los impulsa al consumo, luego los consume? La vejez, que tanta visibilidad ha alcanzado, demuestra que una buena parte de su "positividad" responde a la incoercibilidad de un sistema sin espacio para la voluntad individual. Las herramientas de la investigación antropológica, una vez más, se muestran eficientes en la transmisión de conocimientos que dan luces a legos y doctos. Propongo, de esta manera, una lectura atenta de este libro. 